\title{
Proper bunch management of the French-type superplantain (Musa acuminata $x$ M. balbisiana, AAB) in Puerto Rico ${ }^{1,2}$
}

\author{
Héber Irizarry," Edmundo Rivera," \\ Abraham D. Krikoriañ and José A. Rodríguezi
}

\begin{abstract}
Soon after flowering, bunches of the Musa AAB clone 'Superplátano' (Superplantain) were trimmed to 4,5 or 6 hands to determine the effect of pruning on fruit grade and marketable yields. Unpruned bunches of the horn-fype 'Maricongo' plantain were included as control. Fruits in bunches pruned to 4 and 5 hands exceeded the mean weight of $270 \mathrm{~g}$, a criterion used locally to render horn-type plantains marketable. 'Superplátano' bunches trimmed to 4 and 5 hands yielded 146,800 and 180,200 marketable fruits/ha, respectively. This represented a yield increase of about 26,000 and 59,400 fruits/ha, over the unpruned horn-type 'Maricongo' cultivar. The reduction of hands in the 'Superplátano' bunch significantly increased length, thickness and weight of fruits in the proximal and distal hands.
\end{abstract}

\section{RESUMEN}

Cuido apropiado del racimo del clon 'Superplátano'

(Musa acuminata $\times$ M. balbisiana, AAB), tipo Congo en Puerto Rico

Racimos tiernos del 'Superplátano' se podaron a 4, 5 y 6 manos para determinar el efecto de la poda en el tamaño de las frutas y en el rendimiento. Como control se incluyeron racimos sin podar del plátano 'Maricongo' tipo Cuerno. Las frutas en los racimos podados a 4 y 5 manos excedieron el peso medio de $270 \mathrm{~g}$., criterio utilizado localmente para cualificar como comercial los plátanos tipo Cuerno. Los racimos del 'Superpláłano' podados a 4 y 5 manos produjeron 146,800 y 180,200 frutas vendibles/ha., respectivamente. Estos rendimientos representan un aumento de 26,000 y 59,400 frutas/ha. en comparación con el de

'Manuscript submitted to Editorial Board 20 September 1990.

2This paper cover's work carried out cooperatively between the Agricultural Research Service - USDA and the Agricultural Experiment Station, University of Puerto Rico (AESUPR), Rio Piedras, P. R., in conjuntion with the Department of Biochemistry and Cell Biology, State University of New York at Stony Brook, N. Y.

${ }^{3}$ Research Horticulturist, Agricultural Research Service, Tropical Agriculture Research Station, Mayagüez, P. R.

${ }^{4}$ Agronomist, Agricultural Research Service, Tropical Agriculture Research Station, Mayagüez, P. R.

"Professor, Department of Biochemistry and Cell Biology, State University of New York at Stony Brook, N. Y. 11794-5215.

${ }^{6}$ Associate Agronomist, Department of Agronomy and Soils. 


\begin{abstract}
'Maricongo' sin podar. La reducción de manos en el 'Superplátano' aumentó substancialmente el largo, grosor y peso medio de las frutas en la mano proximal y en la distal del racimo.
\end{abstract}

\title{
INTRODUCTION
}

In Puerto Rico, the Caribbean Basin and elsewhere in the tropics, plantains are marketed as individual fruits. According to local standards, a plantain must weigh about $270 \mathrm{~g}$ or more to be considered marketable. Larger and heavier fruits demand higher prices. To conform with consumer preference in Puerto Rico all fruits that reach the market currently are the so-called horn-type cultivars. About $90 \%$ of the local market is supplied by the horn-type 'Maricongo.'

This cultivar, however, shows a wide range of variability in number and size of fruits per bunch. Irizarry et al. (4) characterized the 'Maricongo' plantain at six locations in Puerto Rico and found that number of fruits per bunch ranged from fewer than 30 to more than 60 with a mean of 46 fruits. Reversion from the horn to the French phenotype was frequent, and the continuous propagation of "off-types" intermingled with high yielding plants progressively reduced the yielding potential of selected clones. At least two stable clones, 'Hartón' (horntype) and the 'Superplátano' (French-type) have been selected from the unstable 'Maricongo'.

At the Corozal substation the reverted clone 'Superplátano' (fig. 1) has the ability of bearing bunches with 7 to 10 hands (averaging 8 hands), and 83 to 143 fruits, with a mean production of 114 fruits (unpublished data). The proximal hand of the bunch contains fruits similar in size to 'Maricongo,' but those in the distal hand have a low probability of qualifying as an acceptable marketable grade. The greater the number of hands and fruits per bunch, the smaller the size of the individual fruits, particularly those in the distal hand. With current agronomic practices, only 'Superplátano' bunches with fewer than 97 fruits have an opportunity to fully develop all fruits to a marketable grade.

The removal of the male-flower bud and the false hand soon after bunch-shooting is a customary practice in the management of bananas. Boncanto (1) studied the effect of early removal of lower hands from the banana bunch on fruit size. Bunches with the fewest hands produced the heaviest, thickest and longest fruits. Calvo and Soto (2), and more recently Irizarry et al. (6), reported that the technique improved the grading of the remaining banana fruits, but at the expense of reducing bunch weight and total yields.

Rodriguez, et al. (8) applied the technique to both horn and Frenchtype plantains. The removal of the 1 to 3 lower hands in the horn-type 'Maricongo' bunch did not significantly influence fruit charateristics, but substantially increased weight and length in the distal hand of Frenchtype plantains. However, the effect on mean weight of all fruits of the 
J. Agric. Univ. P.R. vol. 75, No. 2, APRL, 1991

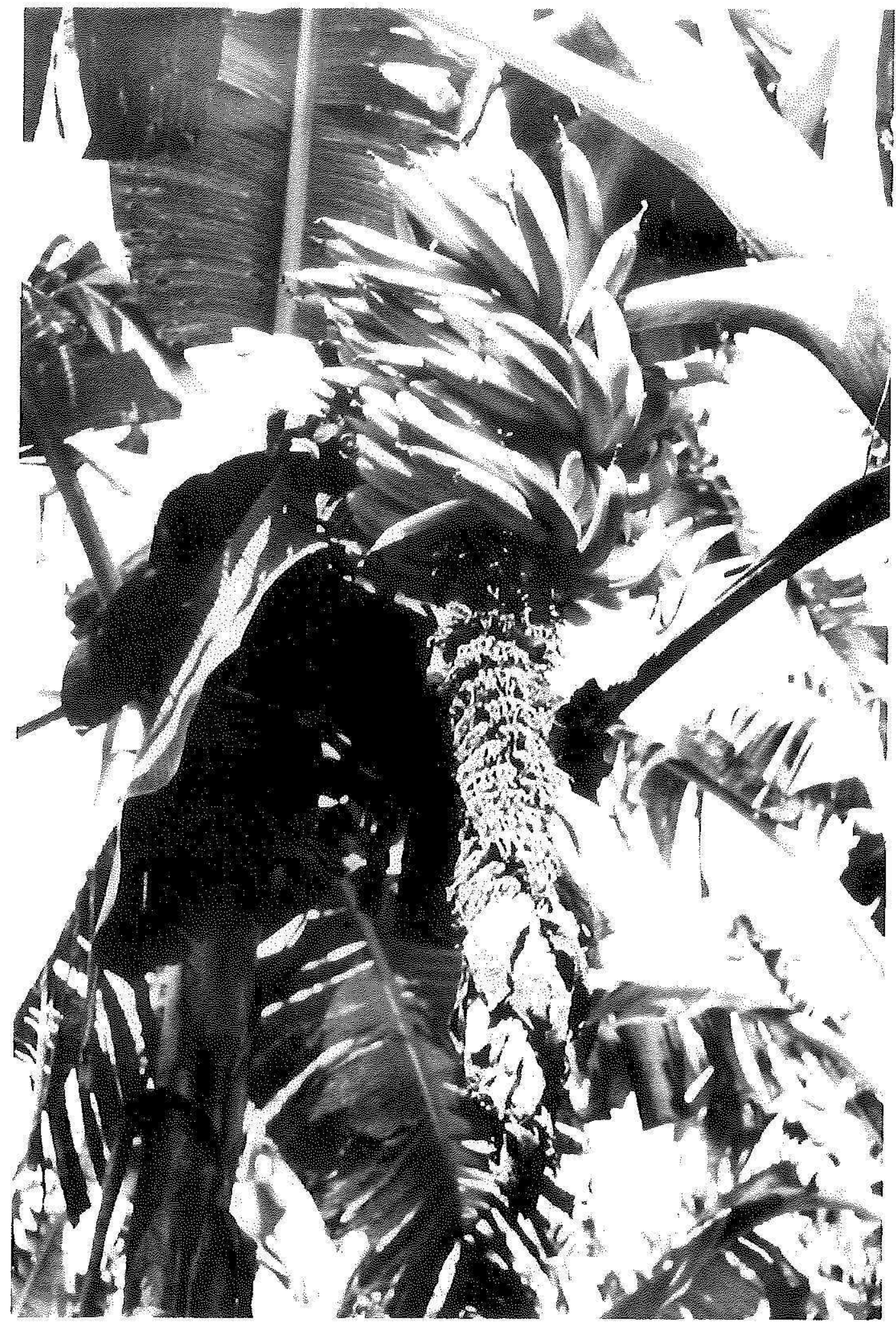

Fig. 1,-Typical unpruned French-type 'Superplátano' bunch. 
pruned bunch was negligible. This was probably caused by the high inherited variability associated with the number of hands and fruits per bunch. This rationale led to the choice of a fixed number of uppermost hands rather than the removal of a given number of lower hands as a more reliable means to upgrade fruit size and increase marketable yields in French-type plantains.

\section{MATERIALS AND METHODS}

'Superplátano' (French-type) and 'Maricongo' (horn-type) plants were regenerated from vegetative tip shoots and male floral bud meristems at the Department of Biochemistry and Cell Biology, State University of New York at Stony Brook, N. Y. $(3,7)$. Three-month-old plants were planted in the field and grown from August 1987 through September 1988. This experiment was established at the AES-UPR Corozal substation, located in the humid north-central uplands, at an elevation of about $200 \mathrm{~m}$. Mean monthly rainfall throughout the experimental cycle was 185 $\mathrm{mm}$ with a pan evaporation of $115 \mathrm{~mm}$. From May through July pan evaporation exceeded rainfall by $22 \%$. Average monthly minimum and maximum temperatures were 19.7 and $30.6^{\circ} \mathrm{C}$, respectively. The soil is a red-acid Corozal clay (Aquic Tropudults, clayey, mixed, isohyperthermic) with a pH of 5.3 , containing $4 \mathrm{mg} / \mathrm{kg}$ of $\mathrm{P}$ (Bray Method 2) and an exchangeable base capacity of $10.6 \mathrm{cmol}(+) / \mathrm{kg}$ of soil.

The plantains were spaced at 1.8 by $2.1 \mathrm{~m}$, about 2,550 plants $/ \mathrm{ha}$. A 10-5-20-3 ( $\mathrm{N}, \mathrm{P}_{2} \mathrm{O}_{5}, \mathrm{~K}_{2} \mathrm{O}$, and $\left.\mathrm{MgO}\right)$ fertilizer supplemented with 25.4 $\mathrm{kg} / \mathrm{t}$ of a minor elements mixture was applied at the rates of about 600 , $800,1,000$ and $600 \mathrm{~kg} / \mathrm{ha}$. The fertilizer was administered at $2,5,8$ and 10 months after planting.

Soil-borne pests, yellow Sigatoka and weeds were controlled in accordance with the Experiment Station recommendations (5).

Immediately after the last hand became visible, the number of hands and fruits per bunch were counted, and the immature 'Superplatano' bunches were subjected to three pruning treatments. The uppermost 4, 5 and 6 hands were left intact whereas the male flower bud and the remaining lower hands were trimmed. Pruning was easily performed from the ground with a $4.6 \mathrm{~m}$ long adjustable aluminum pole with a sharp hooked blade attached to one end (fig. 2). The 'Maricongo' bunches were left unpruned for comparison.

The treatments contained 27 plants (bunches) per plot, and were arranged in a randomized complete block design with four replications.

The bunches were harvested at the mature-gxeen stage, about 105 days after bunch-shooting. At harvest, all bunches were weighed and the fruit mean weight was calculated. The proximal and distal hands of the 'Superplátano' bunch were sampled to determine individual fruit length, diameter and weight. Using Duncan's multiple range test, we compared treatment means. 


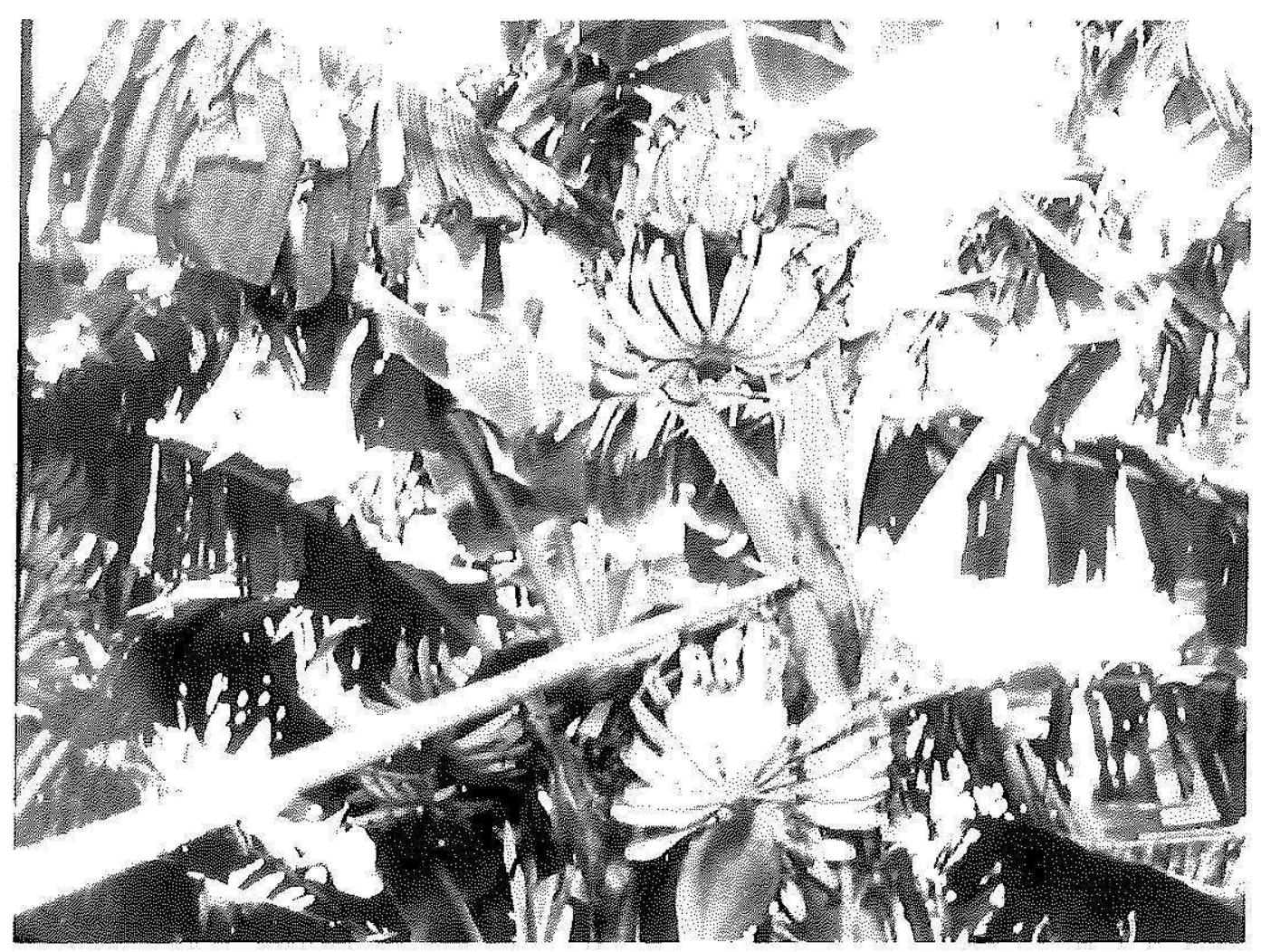

Fig. 2.-Pruning a two-week-old 'Superplátano' bunch from the ground using an adjustable aluminum rod.

\section{RESULTS AND DISCUSSION}

The pruning of lower hands from immature bunches proved to be a reliable technique to upgrade fruits and increase marketable yields in the 'Superplátano.' Mean fruit weight progressively increased at the expense of reducing bunch size from 6 to 4 hands (table 1, fig. 3). Bunches pruned to 4 and 5 hands exceeded the $270 \mathrm{~g}$ of average fruit weight expected from the local annual production of horn-type plantains. Number of fruits and weight per bunch, and total marketable yields were substantially increased over those of 'Maricongo.' The 'Superplatano' bunches pruned to 4 and 5 hands outyielded 'Maricongo' by 26,000 and 59,400 fruits/ha, respectively. However, the unpruned 'Maricongo' bunch produced the heaviest individual fruits.

Fruit size in the proximal and distal hands of the trimmed bunch was affected by pruning (table 2, fig. 4). Significantly longer, thicker and heavier fruits were harvested from bunches pruned to 4 and 5 hands as compared to those with 6 hands. However, only fruits from the distal hand of bunches pruned to 4 hands conformed to the local marketable grade. 

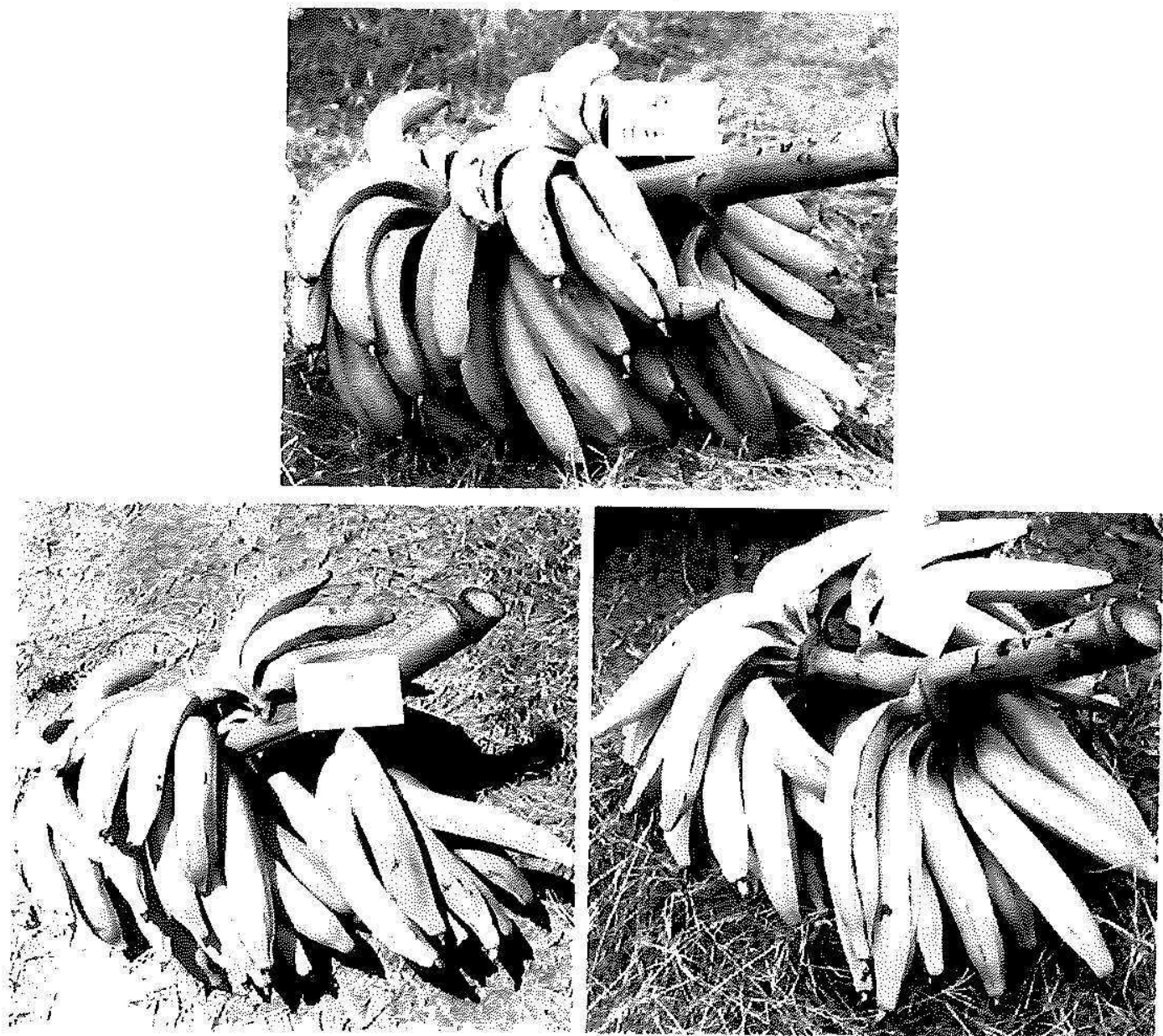

Fig. 3.-Comparison of 'Superplátano' bunches pruned to 6,5 , and 4 hands.

TABI.E 1.-Yield potential of the 'Superplatano' with bunches pruned to a reduced number of hands and the 'Maricongo' unpruned and averaging 7 hands

\begin{tabular}{|c|c|c|c|c|c|}
\hline \multirow{2}{*}{$\begin{array}{l}\text { Cultivar and bunch } \\
\text { pruning treatment }\end{array}$} & \multicolumn{2}{|c|}{ Production per bunch } & \multirow{2}{*}{$\begin{array}{l}\text { Mean fruit } \\
\text { Weight }\end{array}$} & \multicolumn{2}{|c|}{ Production per hectare } \\
\hline & Fruits & Weight & & Fruits & Weight \\
\hline & no. & $\mathrm{kg}$ & $\mathrm{kg}$. & no. & ton \\
\hline 'Superplátano' -6 hands & $83.5 \mathrm{a}^{4}$ & $21.8 \mathrm{a}$ & $261.1 d$ & $212,925 \mathrm{a}$ & $55.6 \mathrm{a}$ \\
\hline 'Superplátano' -5 hands & $70.7 \mathrm{~b}$ & $20.4 \mathrm{~b}$ & $288.5 \mathrm{c}$ & $180,285 b$ & $52.0 \mathrm{~b}$ \\
\hline 'Superplátano' - 4 hands & $57.6 \mathrm{c}$ & $18.3 \mathrm{c}$ & $317.7 \mathrm{~b}$ & $146,880 c$ & $46.7 \mathrm{c}$ \\
\hline 'Maricongo' - unpruned & $47.4 d$ & $17.6 \mathrm{~d}$ & $371.3 \mathrm{a}$ & $120,870 \mathrm{~d}$ & $44.9 \mathrm{~d}$ \\
\hline
\end{tabular}

'Means followed by the same letter do not differ significantly at the $\mathbf{P}=0.05$ probability level. 


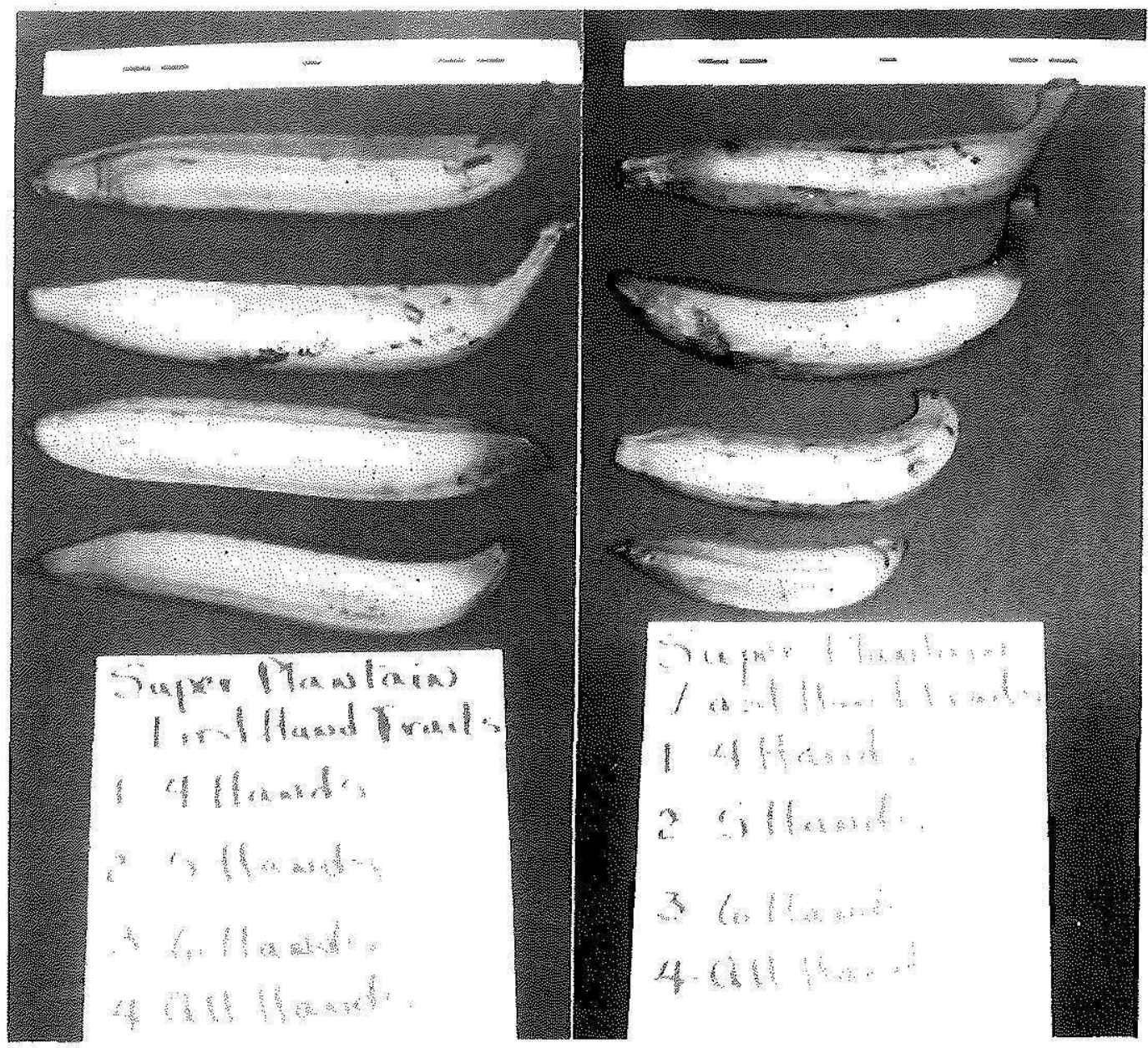

Fig. 4.-Comparison of fruit size in the proximal and distal hands of pruned and unpruned 'Superplátano' bunches.

TABLE 2.-Effect of hands removal on measurements and mean weight of fruits in the proximal and distal hands of the pruned 'Superplatano' bunch

\begin{tabular}{lccccccc}
\hline \multirow{2}{*}{$\begin{array}{l}\text { Hands per } \\
\text { bunch }\end{array}$} & \multicolumn{3}{c}{ Fruits in the upper hand } & & \multicolumn{3}{c}{ Fruits in the lower hand } \\
\cline { 2 - 4 } \cline { 6 - 8 } & Length & Diameter & Weight & & Length & Diameter & Weight \\
\hline No. & $\mathrm{cm}$ & $\mathrm{cm}$ & $g$ & $\mathrm{~cm}$ & $\mathrm{~cm}$ & $\mathrm{~g}$ \\
Four & $24.7 \mathrm{a}^{\prime}$ & $4.45 \mathrm{a}$ & $321.0 \mathrm{a}$ & & $23.2 \mathrm{a}$ & $4.28 \mathrm{a}$ & $270.7 \mathrm{a}$ \\
Five & $24.6 \mathrm{a}$ & $4.44 \mathrm{a}$ & $305.3 \mathrm{a}$ & & $22.7 \mathrm{a}$ & $4.16 \mathrm{a}$ & $224.6 \mathrm{~b}$ \\
Six & $23.5 \mathrm{~b}$ & $4.20 \mathrm{~b}$ & $270.1 \mathrm{~b}$ & $20.9 \mathrm{~b}$ & $3.96 \mathrm{~b}$ & $194.1 \mathrm{c}$ \\
\hline
\end{tabular}

'Means followed by the same letter do not differ significantly at the $P=0.05$ probability level. 


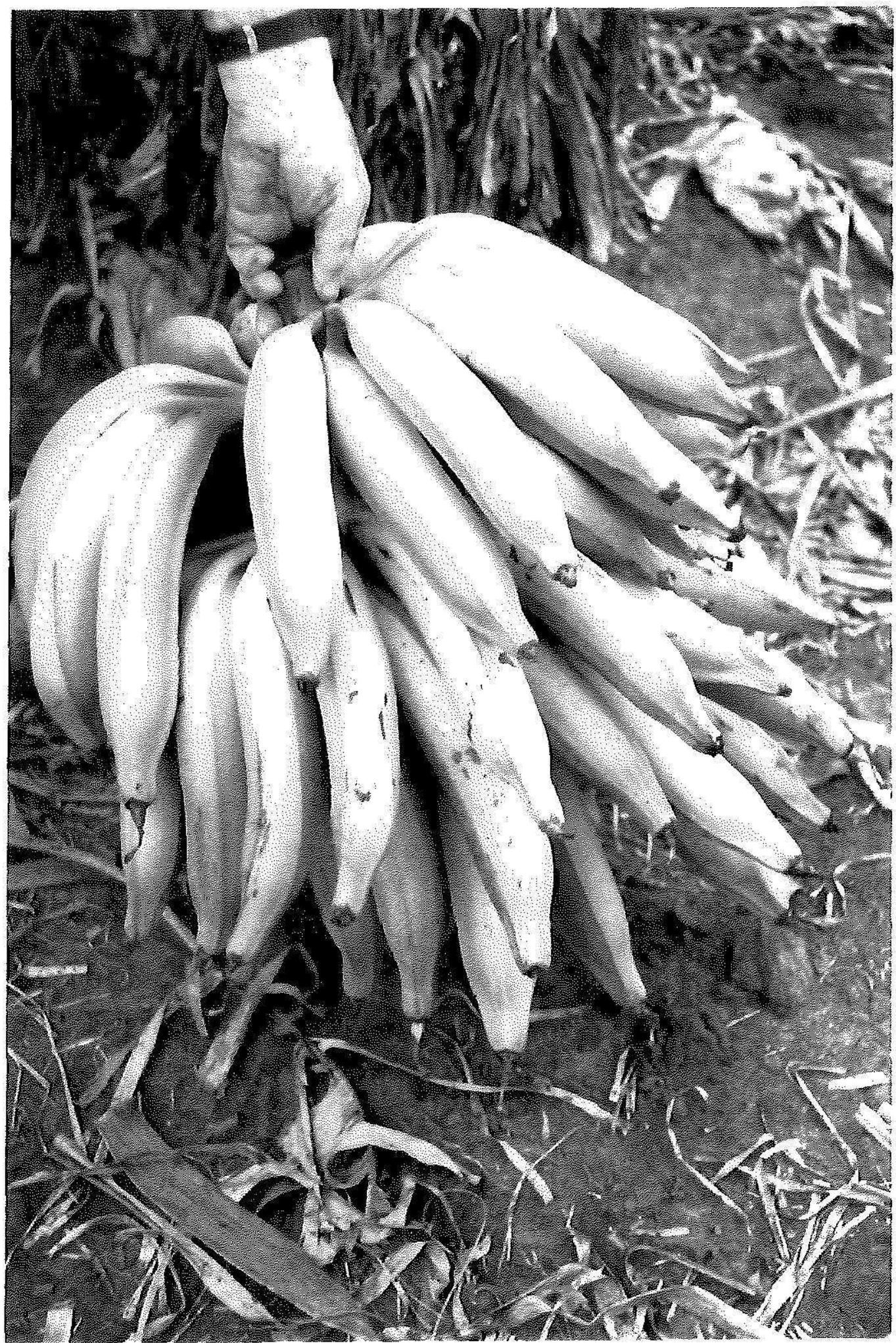

Fig. 5. - Shape of fruits in a pruned 'Superplatano' bunch. 
In addition to the effect on fruit size, pruning influenced fruit shape (fig. 5). Fruits of trimmed bunches lost their normal curvature and grew straight, particularly those in the proximal hand. This may be a desirable trait in fruit packing because it minimizes the use of shipping space.

The application of the bunch pruning technique to the 'Superplátano' and perhaps to other French-type cultivars offers growers an alternative to adjust yields according to farm productivity or prevailing market conditions. During pruning, 2 to 4 hands were removed from the bunches. These lowermost hands averaged 24 to 50 fruits, respectively. This finding indicates that a challenge lies ahead to increase further marketable yields in the 'Superplátano.'

\section{LITERATURE CITED}

1. Boncanto, A. A. 1969. Effects of reducing the number of hands in a bunch of Lacatan banana. Philipp. J. Plant Ind., 32 (2-4): 234-51.

2. Calvo, J. and M. Soto, 1985. Effect of dehanding in banana fruit quality in the "Great Dwarf" cultivar, Musa AAA Cavendish, Proc. ACORBAT, 7th Meet. (Sept. 23-27), San José, Costa Rica. 311-15.

3. Cronauer, S. S. and A. D. Krikorian, 1988. Determinate floral buds of plantain (Musa $\mathrm{AAB})$ as a site of adventitious shoot formation. Ann. Bol. 61: 507-12.

4. Irizarry, H., J. A. Rodriguez and N. Diaz, 1985. Selection and evaluation of high yielding Horn-type plantain clones in Puerto Rico: An explanation for their behavior. $J$. Agric. Univ. P. R. 69 (3): 407-19.

5. — and R. Montalvo-Zapata, 1986. Conjunto tecnológico para la producción de plátanos y guinens. Publ. 97, 2da. ed., Esta. Exp. Agric., Univ. P. R.

6. - E. Rivera, I. Beauchamp de Caloni and R. Guadalupe, 1989. Performance of elite banana (Musa acuminata, AAA) cultivars in four locations of Puerto Rico. J. Agric. Univ. P. R. 73 (3): 209-21.

7. Krikorian, A. D. and S. S. Cronauer, 1984. Banana. In: Handbook of Plant Cell Culture. (W. R. Sharp, D. A. Evans, P. V. Ammirato, Y. Yamada, Eds) vol. 2, 327-48. MacMillan Publishing, New York.

8. Rodríguez, J. A., H. Irizarry and E. Rivera, 1987. Efecto de la poda de manos en el rendimiento y calidad de las frutas del plátano (Musa acuminata $\times M$. balbisiana, AAB). Proc. ACORBAT, 8th Meet. (Sept. 28-Oct. 2), Santa Marta, Colombia. 